\title{
WS044 人間の発達変容をシステムとして捉える試みーTEMを用いてー
}

\author{
企画者: 廣瀬眞理子 (関西学院大学) \\ 企画者: 長坂 晟 (明治学院大学) \\ 司会者: 安田 裕子 (立命館大学) \\ 話題提供者: 番田 清美＃（東京学芸大学) \\ 話題提供者: 和田 美香\#(厚木市立病院) \\ 話題提供者: 長坂 晟 (明治学院大学) \\ 話䟎提供者: 廣瀬眞理子 (関西学院大学) \\ 指定討論者: 安田 裕子 (立命館大学) \\ 指定討論者 : サトウタツヤ (立命館大学)
}

人間は,常に外部と影響し合っている開放系である。個人システムは, 家族システムに埋め込まれ,家族シ ステムは,何らかの集団やコミュニティや社会など,さらに上位のシステムに埋め込まれている。また,個 人システムは,家族システムとは別の位相で,なんらかの集団システムに属してもいよう。複線径路・等 至性モデル（TEM）は,人間の発達や人生径路の多様性と複線性を捉え描き出す質的研究法であるが,そ の特徴は,人間を開放システムと捉えるシステム論（Bertalanffy,1968/1973）に依拠する点時間を捨象 して外在的に扱うことをせず,個人に経験された時間の流れを重視する点にある。本企画では,時間とと もにある人の発達的変容や人生選択の有り様を,TEMをもちいてシステムとしてどのように描くことが できるのかに焦点をあてて,4名の話題提供者に報告をいただく。そして,人の変容をシステムとして捉え ることによってどのようなことが見えてくるかについて考えたい。 